Int. J. Electrochem. Sci., 12 (2017) $4444-4455$

International Journal of

ELECTROCHEMICAL

SCIENCE

WWW.electrochemsci.org

\title{
Electrodegradation of Phenol Through Continuous Electrolysis of Synthetic Wastewater on Platinized Titanium and Stainless Steel Anodes
}

\author{
Grazyna Piotrowska and Boguslaw Pierozynski* \\ Department of Chemistry, Faculty of Environmental Management and Agriculture, University of \\ Warmia and Mazury in Olsztyn, Plac Lodzki 4, 10-727 Olsztyn, Poland \\ *E-mail: bogpierozynski@yahoo.ca, boguslaw.pierozynski@uwm.edu.pl
}

doi: $10.20964 / 2017.05 .74$

Received: 6 February 2017 / Accepted: 29 March 2017 / Published: 12 April 2017

This paper reports on the process of phenol electrodegradation realized through continuous electrolysis of synthetic wastewater. Oxidative degradation of phenol is examined by means of a laboratory size, self-made electrolyser for different anode/cathode configurations, various electrical parameters and phenolic wastewater compositions. Monitoring of phenol decomposition (along with quantitative identification of reaction products) in wastewater is carried-out by means of instrumental HPLC/MS method in function of electrolysis time, also in relation to specific energy consumption.

Keywords: Phenol electrodegradation; Phenol electrooxidation; PhER; Wastewater electrolysis; HPLC/MS analysis

\section{$\underline{\text { FULL TEXT }}$}

(C) 2017 The Authors. Published by ESG (www.electrochemsci.org). This article is an open access article distributed under the terms and conditions of the Creative Commons Attribution license (http://creativecommons.org/licenses/by/4.0/). 